IDEAS BEHIND SYMBOLS - LANGUAGES BEHIND SCRIPTS 
Studia uralo-altaica 52

\section{Redigunt}

Katalin Sipőcz

András Róna-Tas

István Zimonyi 


\section{Ideas behind symbols - languages behind scripts}

Proceedings of the 60th Meeting of the Permanent International Altaistic Conference (PIAC)

August 27 - September 1, 2017

Székesfehérvár, Hungary

Edited by Ákos Bertalan Apatóczky

Szeged, 2018 
(C) University of Szeged,

Department of Altaic Studies,

Department of Finno-Ugrian Philology

Printed in 2019

All rights reserved. No part of this book may be reproduced, stored in a retrieval system, or transmitted in any form or by other means, electronic, mechanical, photocopying, recording or otherwise, without the prior permission in writing of the author or the publisher.

Printed by: Innovariant Ltd., H-6750 Algyő, Ipartelep 4.

ISBN: 9789633066638 (printed)

ISBN: 978-963-306-664-5 (pdf)

ISSN: 01334239 


\section{Contents}

Preface

Tatiana Anikeeva

Turkic Manuscripts and Old-Printed Books of the Lazarev Institute of Oriental

Languages: Exploring the History of Oriental Studies in Russia

Chen Hao

Bark: A Study on the Spiritual World of the Early Türks

Oliver Corff

Nations and Rivers: Their Status and Name in the Qingshi Gao Reflections on the

Draft History of Qing as a Source

Balázs Danka

A language behind the script A case study on the Pagan Oyuz-nāmä

Mihály Dobrovits

The Ogur Turks in Chinese records

Hsiang-Tai Kao

The field research on the Manchu inscriptions in Beijing

Bayarma Khabtagaeva

Some notes on kinship terminology in Yeniseian.

Kyoko Maezono

Japanese and Mongolian Usages of the Chinese Writing System

Dieter Maue - Mehmet Ölmez - Étienne de la Vaissière - Alexander Vovin

The Khüis Tolgoi inscription

Rodica Pop

The "five eyes pattern" tavan nüden hee

Maria Magdolna Tatár

Bortz and Membrok, etymology of two Cuman names from the 13th century.....107

Hartmut Walravens

Józef Kowalewski’s Letters to Bernhard Jülg.

Tana $\mathrm{Wu}$

One Language behind Two Different Scripts*

Hülya Yıldız

New Reading Proposal on the Eastern Face, Nineteenth Line of the Bilgä Qayan Inscription 



\title{
New Reading Proposal on the Eastern Face, Nineteenth Line of the Bilgä Qayan Inscription
}

\author{
Hülya Yıldız \\ Anadolu University
}

\section{Introduction}

It has been more than 120 years since Vilhelm Thomsen deciphered (1893) the alphabet of runic inscriptions erected in the Orkhon and Yenisei regions. During this long period, a variety of runic inscriptions belonging to Old Turkic communities have been continuously discovered and investigated by many scholars. Today, the relatively well-understood ones among all Old Turkic runic inscriptions are the Orkhon inscriptions, primarily those of Köl Tegin, Bilgä Qayan and Tuńuquq (henceforth will be referred to as KT, BQ, T). However, even these three inscriptions preserve some of their mysteries. This is because some parts of the inscriptions are worn off and consequently the readings and the meanings of some lexemes are unclear. Therefore, the interpretation of some parts of the inscriptions is difficult and several reading proposals are put forward in the literature.

One of the most problematic parts in the history of the Old Turkic runic studies is in the 19th line of the BQ inscription. This part is inscribed exactly between $<$ BWDN $>$ and $<\mathrm{kW}$ rgẄnn $>$ sign groups in the mentioned line. The colleagues who studied on the inscription so far deciphered and interpreted this sequence in different ways. However, those researchers did not pay attention to orthography and the grammatical structure of the sentence in their reading proposals. As a result, their translations became grammatically and semantically invalid.

The present paper attempts to reconsider this group of problematic signs attested in the 19th line of the BQ inscription. Here the research history of the inscription will be evaluated, and a new reading and interpretation regarding the problematic sequence will be proposed. The paper is organized as follows: Section 1 is Introduction. In Section 2, the major studies on the BQ inscription will be dealt with respectively. In Section 3, a new reading proposal will be made regarding the problematic part of the line. Finally, Section 4 presents the conclusions. In the running text, angle brackets $<>$ stand for graphemic writings while square brackets are used for reconstructions. 


\section{The Major Studies on the Bilgä Qayan Inscription}

The BQ inscription, discovered in 1889 by Yadrintsev, was studied by many scholars so far. Among these studies Heikel et al. 1892, Radloff 1893, 1895 and Thomsen 1896 are of particular importance not only because these studies have been the first investigations on the inscription but also because they are utilized as the main references by the later colleagues.

The research history of the BQ starts with the monumental work Inscriptions de l'Orkhon, known also as Finnish Atlas, which was edited under the leadership of Axel Olai Heikel, in 1892. For the research of the BQ inscription or of the Orkhon inscriptions in general, this atlas contains important information on what was visible on the steles at that time. Additionally, the fact that Finnish scholars didn't know how to read the runic script and didn't have any vision motivated by their reading expectations, thus without bias, makes the given data even more objective and in some cases more convenient, as can be seen below. In this source, the text of the BQ in printed runic typefaces is given between 12nd-23rd pages in Arabic numerals and the unretouched copy of the eastern face of the inscription can be seen in the Table 27. When this source is attentively checked it is understood that those scholars numbered the eastern face of the BQ starting from the end. It means, the last (=41st) line in the eastern face of the inscription is equal to 1st line in the Finnish Atlas and consequently the 19th line, which is the subject of the study at hand, is equal to the 23rd one.

Wilhelm Radloff's Atlas der Alterthümer der Mongolei, known also as Radloff's Atlas, is one of the major references for the research of Old Turkic inscriptions. This work was published in four fascicules between 1892 and 1899. The second fascicule, published in 1893, contains unretouched and retouched photographs of the rubbings of the BQ (see Plates 21-25). Plate 22 is the unretouched copy and Plate 23 is the retouched copy of the eastern face of the inscription. The Plate 22 is one of the major sources to which I will mainly refer in my paper. Because, this plate does not show the signs which were "expected" to be there but the ones which really "existed" on the stele.

Radloff's other work, Die alttürkischen Inschriften der Mongolei (1895), contains the text of Bilgä Qayan inscription in printed runic typefaces together with a translation to German. When Radloff's unretouched copy (Plate 22) and his printed text in runic typefaces (pp. 42-82) are attentively compared, it turns out that the retouches regarding the mentioned sign group contain some reconstructions that cannot be confirmed. However, as will be shown in this study, some later researchers relied on Radloff's retouches too trustingly and did not question the correctness of them.

Thomsen's Inscriptions de l'Orkhon Déchiffrées, published in 1896, is also one of the major references for the research of the Old Turkic inscriptions. There were no runic typefaces presented in this source. Thomsen himself $(1893,286)$ stated that 
he both utilized the Finnish Atlas and Radloff's Atlas but he preferred the typographic reproductions presented in the Finnish Atlas in case of divergences between the same texts in those two works. The second section of Thomsen's book is dedicated to the translations of the $\mathrm{KT}$ and $\mathrm{BQ}$ inscriptions. In this reference, the parallel passages of those two inscriptions were not presented and therefore translated separately. Concerning the continuation of the end of BQ E 2 to the beginning of 24 , Thomsen $(1896,122)$ referred to the pages $97-108$, which includes the parallel passage of the KT.

When major studies and the subsequent ones mentioned above are examined, it can be seen that there was no consensus among scholars on which signs the sequence in question consisted of. One may see how that problematic sign group was transliterated or transcribed so far in a comparative table below:

\begin{tabular}{|c|c|c|c|c|}
\hline \multicolumn{2}{|c|}{ References } & $\begin{array}{l}\text { Transliterations } \\
\text { of the given } \\
\text { runic typefaces }\end{array}$ & Transcriptions & Translations \\
\hline \multicolumn{2}{|c|}{$\begin{array}{l}\text { Finnish Atlas } \\
(1892)\end{array}$} & rtzTẅk̈n (p. 15) & - & - \\
\hline \multicolumn{2}{|c|}{$\begin{array}{l}\text { Radloff's Atlas } \\
(1893) \\
\text { (retouched copy) }\end{array}$} & rtz//In (plate 23) & - & - \\
\hline \multirow{2}{*}{\multicolumn{2}{|c|}{$\begin{array}{l}\text { Radloff (1895) } \\
\text { (printed runic } \\
\text { typefaces) }\end{array}$}} & \multirow[t]{2}{*}{$\left.\mathrm{rtn}: \frac{\ddot{\mathrm{W}}}{\underline{\mathrm{w} k} \mathrm{k}}\right)^{1} \mathrm{Wn}(\mathrm{p}}$. & ärtin (p. 55) & 'du warst'2 $(\mathrm{p}$. \\
\hline & & & ökün (p. 55) & 'bereue' (p. 54) \\
\hline \multirow[t]{3}{*}{ Thomsen } & \multirow[t]{2}{*}{$(1896)$} & \multirow[t]{2}{*}{-} & \multirow[t]{2}{*}{ ärt.z $\underset{105)}{\text { ökü }(p . ~}$} & $\begin{array}{l}\text { ärt.z - not } \\
\text { translated }\end{array}$ \\
\hline & & & & $\begin{array}{l}\text { ökün 'repens- } \\
\text { toi!' (p. 105) }\end{array}$ \\
\hline & (1924) & - & - & $\begin{array}{l}\text { 'Zittre und geh } \\
\text { in dich' (p. } \\
149)^{3}\end{array}$ \\
\hline \multicolumn{2}{|c|}{ Orkun (1936) } & -4 & ärt.z ökün (p. 40) & $\begin{array}{l}\text { 'kendine dön!' } \\
\text { (p. 40) }\end{array}$ \\
\hline
\end{tabular}

1 In Radloff's runic typefaces actually there is $<\mathrm{rtn}>$ but he transliterates it as $r t n$ in page 55.

2 Radloff's $d u$ warst 'you were' translation was criticized by Thomsen from the vantage point of Old Turkic grammar. Thomsen $(1896,151)$ justly stated that 'you were' was rendered as ärtig not *ärti everywhere and without any exception.

3 Later, he interpreted ärt.z ökün as above.

4 Orkun (p. 41) just gives the parallel passage of the KT text in runic typefaces. 


\begin{tabular}{|c|c|c|c|c|}
\hline \multirow[t]{2}{*}{ Tekin } & (1968) & - & $\begin{array}{c}\text { ärtin ökün (p. } \\
\text { 329) }\end{array}$ & $\begin{array}{l}\text { '(?) to regret, } \\
\text { repent' (p. 329, } \\
363)\end{array}$ \\
\hline & (1988) & - & $\begin{array}{c}\text { ärtin:ökün (p. } \\
56)\end{array}$ & $\begin{array}{l}\text { 'vazgeç (ve) } \\
\text { nadim ol' (p. } \\
57)\end{array}$ \\
\hline \multicolumn{2}{|c|}{ Alyılmaz (2005) } & $\mathrm{rtn}: \ddot{\mathrm{W}}_{\underline{129})}^{\underline{\mathrm{w} k}} \ddot{\mathrm{Wn}}(\mathrm{p}$. & - & - \\
\hline \multicolumn{2}{|c|}{ Berta (2007) } & rtz: $\frac{\ddot{\mathrm{W}} \mathrm{w} k \mathrm{~W} n}{109)^{5}}$ (p. & -6 & -7 \\
\hline \multicolumn{2}{|c|}{ Ólmez (2012) } & rtn: $\ddot{\mathrm{W}}_{\underline{153})} \frac{\ddot{\mathrm{w}} \mathrm{W}}{\mathrm{153}}(\mathrm{p}$. & $\begin{array}{c}\text { ärtin:ökün (p. } \\
126)\end{array}$ & $\begin{array}{l}\text { 'pişman ol (ve) } \\
\text { tövbe et!' (p. } \\
140)\end{array}$ \\
\hline \multicolumn{2}{|c|}{ Aydın (2012) } & rtn: $\frac{\ddot{W}}{40)}$ w & $\begin{array}{c}\text { ärtin:ökün (p. } \\
40)\end{array}$ & $\begin{array}{c}\text { 'pişman ol!' (p. } \\
40)\end{array}$ \\
\hline
\end{tabular}

Table 1: The sign group in question in the previous researchers' studies

As it is easily visible to the reader, there are some important differences among the scholars concerning the identification of glyphs and the interpretation of the sequence. As is seen in the table above, most of the scholars starting from Radloff 1895 displayed the first three signs as $<\mathrm{rtn}>$ while there was $<\mathrm{rtz}>$ in the Finnish Atlas, Radloff 1893 (retouched copy), Thomsen, Orkun and Berta. The fourth sign was displayed as a doubtful $<\mathrm{T}>$ by Finnish Atlas while Radloff 1895 and the subsequent researchers interestingly gave a separation mark instead. Despite the last four signs were recorded as $<\ddot{\mathrm{W}} \underline{\ddot{\mathrm{w}} \mathrm{k}} \ddot{\mathrm{W}} \mathrm{n}>$ in all studies, Finnish Atlas did not give any $<\ddot{\mathrm{W}}>$ before the sign $<\underline{\mathrm{w} k}>$ in the middle. Then, today's researcher who intends to make a new proposal on the mentioned sign group should begin by clarifying from where these differences are derived above all.

5 Berta did not present the parallel passages of the KT and the BQ inscriptions respectively. Instead, he gave the eastern face of the KT as the main text and referred to the differences in footnotes. For the transliteration of the problematic sequence in BQ, see footnotes 354 and 355.

6 Since Berta gave the eastern face of the KT as the main text, we just find the reconstructed form ärDin (p. 153) for the word in the 22nd line of the KT. However, in the footnote 1387, Berta states that for the parallel passage in BQ, there is ärt.z in Thomsen, rtz in Tekin 1968 and ert.z in Orkun.

7 In his translation, starting from the page 190, Berta did not treat the parallel passages respectively, either (see. p. 196). Consequently, the translation of the given sequence in Bilgä Qayan cannot be found separately. However, it can be seen that Berta translated the reconstructed form ärDin in the 22nd line of the KT as 'voltál' despite he did not translate the word $\ddot{o k} \ddot{w} n$ in the same line. 
The first three signs: To clarify the differences pointed above, the unretouched copies of the BQ given by Finnish scholars (1892) and Radloff (1893) should be taken as the starting point since they are the oldest records of the inscription at hand. However, the unretouched copy in the Finnish Atlas is not that convenient for this kind of review since the signs in that part of the inscription were not clearly visible in that copy:

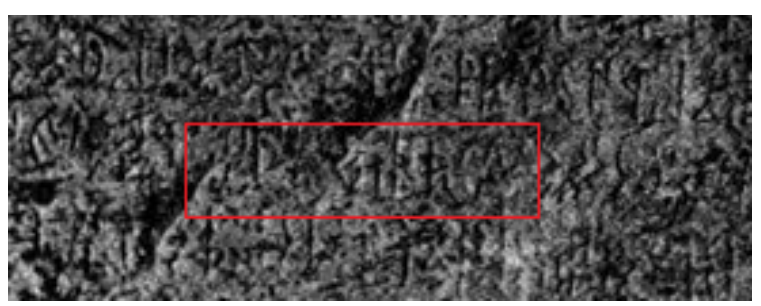

Figure 1: Heikel et al. 1892, unretouched copy (Table 27)

Then it would be better to start with the unretouched copy in Radloff's study (Plate no: 22). Here is the partial appearance of the line 19, including the sign group in question, in a slightly enlarged scale:

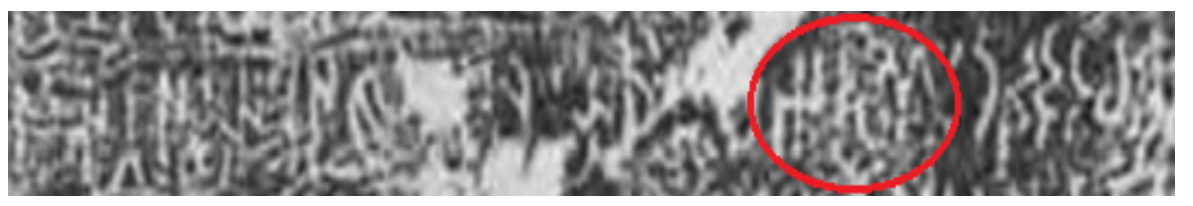

Figure 2: Radloff 1893, unretouched copy (Plate 22)

As can be seen above the first three signs of this problematic part were obviously and indisputably $<\mathrm{rtz}>$. What was interesting at that point was that Radloff himself also recorded the third sign as $<\mathrm{z}>$ at first. On the retouched copy in his Atlas der Alterthümer, the third character was given as $<\mathrm{z}>$ :

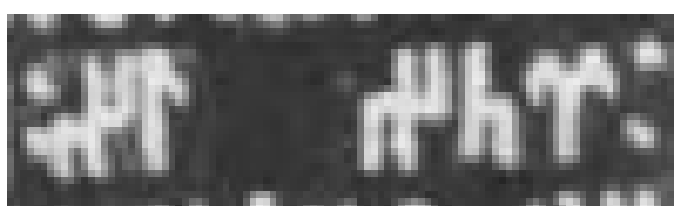

Figure 3: Radloff 1893, retouched copy (Plate no: 23) 
However, in his Die alttürkischen Inschriften, Radloff $(1895,54)$ arbitrarily $^{8}$ gave the third sign as $*<\mathrm{n}>$ as can be seen below:

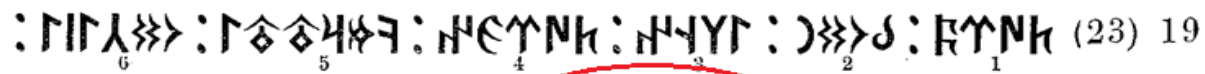

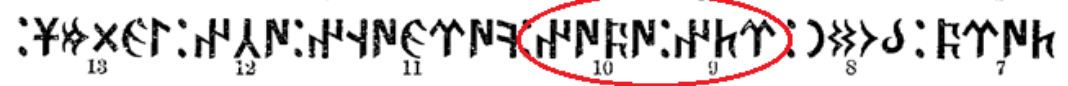

Figure 4: The line 19 in printed runic typefaces in Radloff 1895

It is difficult to know why Radloff made such a falsification because he didn't write anything on the matter in that publication. Therefore, possible explanations may just be based on assumptions. One possible explanation may be that he tended to consider the sign $<\mathrm{z}>$ as a scribal error instead of $<$ n $>$ since these two are very similar in runic script.

The fourth sign: When we refer to Radloff's unretouched copy to identify the fourth sign, we may see it was not easy to identify it due to some erosion on the stone:

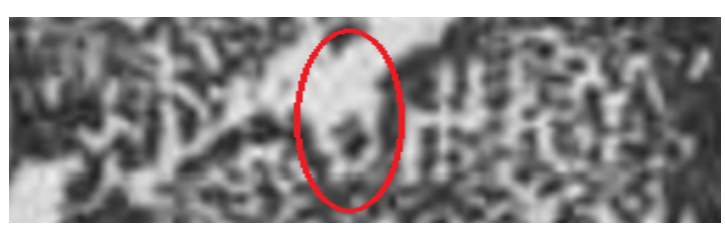

Figure 5: Radloff 1893, unretouched copy (plate no: 22)

However, the remnants of a complicated sign can be identified despite the fact that the lower part is slightly visible and the upper part is completely destroyed due to a crack on the stone. The Finnish scholars approached prudently and gave a doubtful $<\mathrm{T}>$ at that point. However, the identification made by the Finnish scholars was erroneous since the sign $<\mathrm{T}>$ was the one which should be used in a sequence consisting of back velar signs. Radloff (1893) was not able to identify the sign inscribed there and gave a lacuna in his Atlas der Alterthümer as is seen in the Picture 2 above. Thomsen, who benefited greatly from the Finnish Atlas, did not regard the erroneous $*<\mathrm{T}>$ given in the Finnish Atlas and did not include it into his study. However, he completely ignored the existence of the sign at that point and transcribed the sequence as ärt.z ökün. The dot here pointed out that it was unclear whether the word would be read as *ärtäz or *ärtiz.

In Die alttürkischen Inschriften (1895), Radloff made some new touches regarding the sign group in question: First he added a separation mark after the third sign and then an $*<\ddot{\mathrm{W}}>$ as the fourth one. However, neither that separation mark nor

8 As outspokenly stated by Thomsen $(1896,151)$. 
that $*<\ddot{W}>$ can be confirmed by the unretouched copy since there was nothing similar to a colon (which was used as a separation mark in runic alphabet) or the straight vertical line of the sign $<\ddot{W}>$ (see Figure 4 above). At this point, as it is before, it is difficult to know why Radloff made those retouches since he didn't write anything on the matter in his study. But it is possible to make the following assumption about it: As is known, Radloff, who had been defeated by Thomsen in the battle of deciphering the runic alphabet, was in hurry to be the first to publish the Orkhon inscriptions. For that reason, he couldn't pass without making a good or bad proposal on such kind of challenging parts. In my humble opinion, he thought that the last part of the sequence, ending with $<\underline{\ddot{\mathrm{w}} \mathrm{k}} \ddot{\mathrm{W}} \mathrm{n}>$, would give the verb Old Turkic ökün- 'to repent, to regret' (Clauson, 1972, 111). Hence the last three signs should be preceded by an $<\ddot{\mathrm{W}}>$ and the supposed words *ärtin and *ökün should have been separated by a mark. Nevertheless, those markings did not reflect the truth.

At this point it should be noted that the Finnish scholars, who didn't know how to read the runic script and consequently didn't have any vision motivated by their reading expectation, recorded the sequence as $<$ rtzT $\underline{\ddot{w} k} \ddot{\mathrm{W}} \mathrm{n}>$, without any separation mark and an $*<\ddot{W}>$ in the middle.

Radloff's above-mentioned falsifications caused this trouble in the literature: After Radloff 1895, even Thomsen, Orkun and Berta, who correctly identified the third sign as $\langle\mathrm{z}>$, took the sequence with a phantom separation mark and an $*<\ddot{\mathrm{W}}>$ in the middle. In other words, after Radloff 1895 , everyone was convinced that there existed an $\langle\ddot{\mathrm{W}}>$ and a separation mark before the sign $<\underline{\mathrm{w}} \mathrm{k}>$ and the second word could be read as *ökün-. Because, they did not question the accuracy of Radloff's retouches, which led them to repeat the errors made by Radloff.

Now, we can go back to the question of what the fourth sign actually is. To tell the truth, it is hard to judge what sign was inscribed as the fourth one by checking the remnants in the unretouched copy of the inscription given by Radloff (see Figure 4 above). Therefore, at this point, it would be better to refer to an actual photograph of the inscription taken by Mehmet Ölmez in 2011:

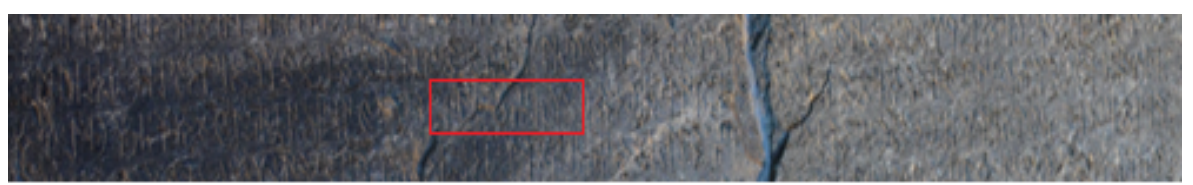

Figure 6: The exact place of the sign group in question on the stele

The exact place of the problematic sequence in the 19th line is shown in red rectangle and one may see the selected sequence in an enlarged scale below:

9 I would like to express my deepest thanks to my preceptor Professor Dr. Mehmet Ölmez, who generously shared the photograph with me and kindly allowed me to use it. 


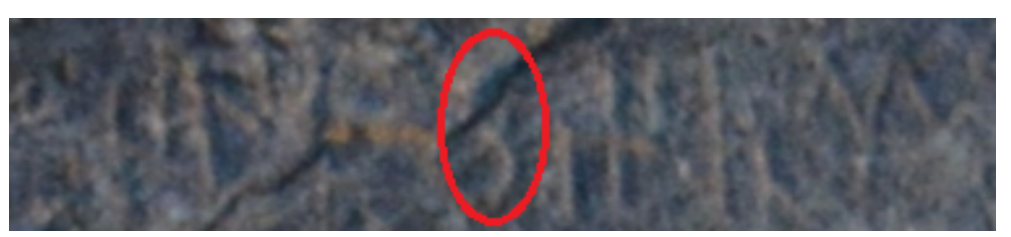

$\begin{array}{lllllll}7 & 6 & 5 & 4 & 3 & 2 & 1\end{array}$

Figure 7: The state of preservation of the fourth sign today.

In this partial appearance of the actual photograph of the inscription, it can be seen clearly that the first three signs of the the sequence in question are well preserved, even in our day, as $\langle\mathrm{rtz}\rangle$. As for the fourth sign, it stands there as a complete surprise. The lower half and the crossing central part of the sign $<$ ń $>$ are still visible on the stone:

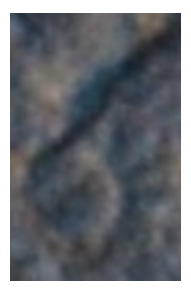

Figure 8: The fourth sign in enlarged scale

However, since only the upper half is defected it should be reconstructed as [ń].

The last three signs: The last three signs are uncontroversial among the scholars except for Radloff 1893, regarding the sixth one. The Finnish Atlas, Radloff 1895 and Thomsen identified an $<\underline{\ddot{w} \mathrm{k}}>$ as the fifth sign, which can be confirmed by the unretouched copy (see picture 4 above) and the findings in Finnish Atlas. However, the fifth sign is completely destroyed in our time as is seen here:

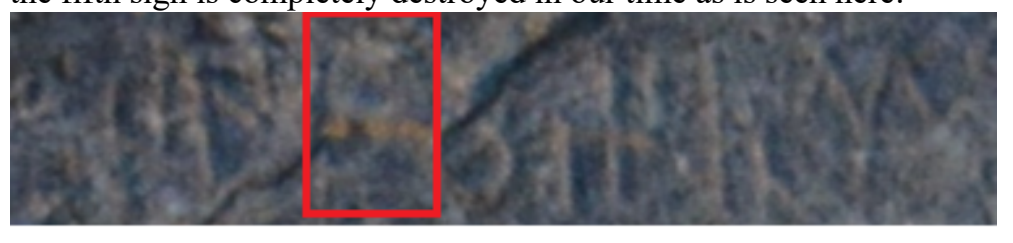

$\begin{array}{lllllll}7 & 6 & 5 & 4 & 3 & 2 & 1\end{array}$

Figure 9: The state of preservation of the fifth sign today

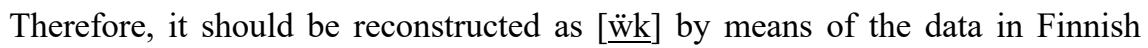
Atlas and Radloff's unretouched copy. As for the sixth sign, Radloff identified an $*<\mathrm{I}>$ in 1893 and then, in 1895 , he gave an $<\ddot{\mathrm{W}}>$ as done by the Finnish scholars and Thomsen. At this point, it should be noted that the sign $<\ddot{W}>$ may be clearly 
identified as the sixth one even in our day, as can be seen on the photograph above. Finally, as for the seventh and the last sign, in Radloff's unretouched copy (see Figure 4 above) an $<\mathrm{n}>$, of which the left lower part was a little defective, is visible. Its state of preservation became worse in course of time (see Figure 7 above). However, depending on the data at hand, it may also be reconstructed as $[\mathrm{n}]$.

\section{A new reading proposal on the problematic sequence}

In the section above, the previous decipherments of the sequence in question were evaluated and the problematic identifications were eliminated by a thorough analysis of the data in the Finnish Atlas (1892), Radloff's (1893) unretouched copy and the actual photograph of the inscription taken by Ölmez in 2011. As a result, it was shown that the sign group in question was inscribed as $<\operatorname{rtz}[\mathrm{n}][\ddot{\mathrm{w} k}] \ddot{\mathrm{W}}[\mathrm{n}]>$. My opinion is that this sign group consisted of two components as follows:

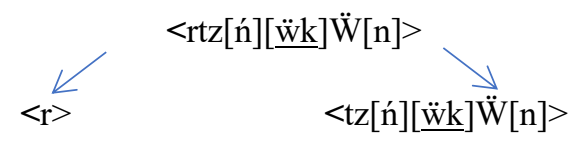

In my opinion, the first sign here gives a very familiar word: $\ddot{a} r$ 'man'. This very short word, which was represented with only one sign in the runic script, was generally inscribed adjacently to the previous sign group when it was used in the nominative case: <brčkr> bärčik är 'the Persians' (KT N 12), <ytlyzr> yetti y[ü]z är 'seven hundred men' (KT E 13), <Lpr> alp är 'brave men' (KT E 40), <lgčAr>

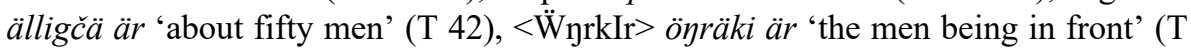
$25)$. But, in our case, the sign $<r>$ was exceptionally inscribed adjacently to the subsequent sign group. There is one more exceptional instance in Orkhon Turkic in which the sign $<r>$ was inscribed adjacently to the previous sign group, as in our case: $<\mathrm{rTbW} \underline{\mathrm{t} I}>\ddot{a} r$ at bultı (KT E 31). However, the previous researchers took the $\operatorname{sign}<r>$ in the sequence $<\mathrm{rtz}[\mathrm{n}][\ddot{\mathrm{w}} \mathrm{k}] \ddot{\mathrm{W}}[\mathrm{n}]>$ together with the following two signs as a lexical unit as $*<$ rtz $>$ (or even more erroneously as $*<\mathrm{rtn}>$ !) and tried to read and interpret it accordingly.

The remaining sign group, $<\mathrm{tz}[\mathrm{n}][\underline{\mathrm{w} k}] \mathrm{W}[\mathrm{n}]>$, may be proposed to be read as täzi[nüuk] $\ddot{u}[n]$ as it is. In my opinion, the structure here includes the Old Turkic verb täz- 'to run away, to fly' (Clauson 1972: 572a), which was used as a hendiadys ${ }^{10}$ with the synonymous verb kürä- 'to run away, to desert' (Clauson, 1972, 737) in the 19th line of the inscription:

10 See also the hendiadys täzdi kürädi 'fled and ran away' in Man.-uig. Frag. 400, 3 (Clauson, 1972, 737). 


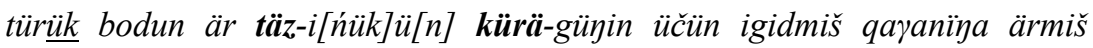

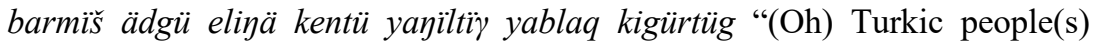
(and) men! Because you are runaway(s) (and) deserter(s), you yourself misbehaved against your Qayan who nourished you and against your free and independent good realm, you brought evil!"

The phrase Türük bodun är "(Oh) Turkish people (and) men!" in my proposal may seem ungrammatical at first sight. However, when it is compared with the expression Türk bäglär bodun "Turkic begs and people" (KT E 10), it turns out that it is correct.

As for the fact that some Turkic peoples ran away altogether or in groups of several men, it is a phenomenon outspokenly uttered in the Orkhon inscriptions. Here one may find numerous mentions about it in addition to the sentence cited above: uluү erkin azqüna ärin täzip bardï "Ulug Erkin run away with a few men" (KT E 34); otuz artuqï tört yašima oүuz täzip tavyačqa kirti "When I was thirty four

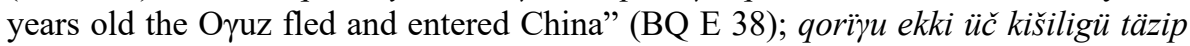
bardï "The guard fled together with two or three people" (BQ E 41); käligmä bäglärin bodunïn etip yï̈̈̈р azča bodun täzmiš ärti "A few people ran away, organizing and assembling their begs and people when they came" (T 43).

To analyse the structure of the word täzi [niük] $\ddot{u}[n]$, it would be better to begin with täz-i[ńük]. I propose the word täz-i[ńük] to be interpreted as 'a deserter"11 and the structure of the word to be analysed as täz- (verb) *-(I)n- (reflexive voice) *-yük (deverbal noun/adjective). Consequently, it should be noted that the $-n$ - in this word was not an original one but a compound sound with the crasis of $-n-y$ - into $-n-$ -

The reflexive form täzin-, which was not attested in Orkhon or Old Uighur Turkic, was recorded in the last period of the Eastern branch of Old Turkic. Kaš gave it with the nuance of 'to pretend to run away' (Clauson, 1972, 576). At this point, it should be noted that there are relatively many examples in Kaš $\gamma a r i ̂$ 's dictionary that the reflexive voice suffix -(I)n-acquired the meaning 'to pretend to do something' in the last period of Old Turkic: ačin- 'to pretend to open' (Clauson, 1972, 29b), bičïn- 'to cut by oneself; to pretend to cut' (Clauson, 1972, 296a), ägrin'to spin for oneself; to pretend to spin', etc. However, the basic and the older meaning of the verb täzin- should have been 'to run away by oneself (on one's own)'.

The deverbal noun suffix $-y U k$, actually a conjugational suffix (Clauson, 1972, xliv), was used as past or past perfect tense marker or formed some intransitive nouns or adjectives (Gabain, ${ }^{3} 2000$, para. 152, 218; Erdal, 2004, 300) in Old Turkic. Since the suffix $-y U k$ forms nouns or adjectives in Old Turkic, the proposed lexeme

11 To analyse in detail, it is a person who ran away in the past at least once (or may be more than once), thus known as 'a runaway'. 
täz-i[ńük] can be interpreted as 'a deserter'"12. At this point, some colleagues may reject that the form $-y U k$ was in use only in Uygur as stated by Gabain ( $\left.{ }^{3} 2000\right)$ and Erdal (2004). However, it should be noted that the participle - $g l I$ which was very typical in Old Uygur was also attested in Orkhon Turkic only in the instance $\ddot{a} r-k l i<$ * är-gli (Erdal, 1994, 78). Therefore, if the proposed form täzi[n̈ük] is confirmed, it may be recorded as its first instance of $*_{-} y U k$ in the language of Turkic runic inscriptions.

As stated above, the word täzi[nük] $\ddot{u}[n]$ was used as a hendiadys with the

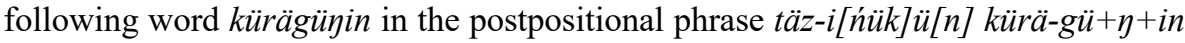
$\ddot{u ̈ c u ̈ n ~ " B e c a u s e ~ y o u ~ a r e ~ d e s e r t e r(s) ~ a n d ~ r u n a w a y(s) ~ . . . " . ~}{ }^{13}$ The grammatical structure of the second word kürägünin may easily be analysed as < kürä- (verb), -gü (deverbal noun) ${ }^{14},+\eta$ (second person possessive), + in (the accusative case coming after possessives). However, it is difficult to say the same for $* t \ddot{z} z-i[$ ń $\ddot{u} k]+\ddot{u}[n]$ structure. At this point, two possible approaches can be put forward on the matter. The reasons for the first one are as follows: (1) The suffix $+n$ at the end of the structure may be the accusative case that comes after possessives because the postpositon $\ddot{u}$ čün 'for; because' requires the accusative case in Old Turkic. (2) The postposition $\ddot{u} \ddot{c} \ddot{u}$, governing the accusative forms of pronouns, also governs the accusative of nominals with second or third person possessive suffix (Erdal, 2004,

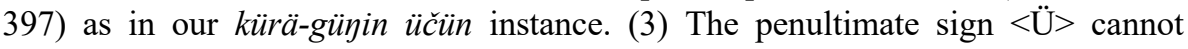
represent the third person possessive since its vowel was always unrounded in Old

12 For further examples that the suffix $-y U k$ is not only an inflectional suffix, but may derive nouns/adjectives as well, see Gabain, ${ }^{32000}$, para. 152 and 218; Erdal, 2004, 300. Also see Old Turkic bulyanyuq 'mixed, turbid, confused' (in bulyańuq Clauson, 1972, 338).

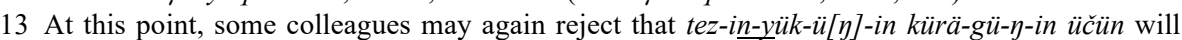
not mean "Because you are runaways and deserters..." since there is no copula in the clause. However, it should be noted that there are two different ways in the literature to translate the

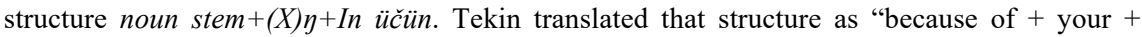

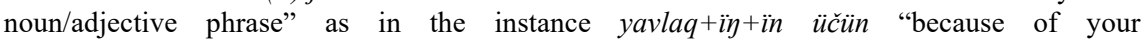
mischievousness" $(1968,267)$ while Erdal $(2004,484)$ translated the same as "because you are bad (= because + you are + noun/adjective)" despite there is no copula in the structure. Here, I follow Erdal's opinion and this is why I translate täziniükü[n]in kürägünin üčün as "Because you are runaway(s) (and) deserter(s)".

14 The morpheme $-g U$ was used in different functions in Old Turkic: 1 . Necessity and obligation; 2. Deverbal noun (Gabain ${ }^{3} 2000$; Erdal 2004); 3. Projection participle which is used for presenting projections of expectation, evaluations and intentions of persons (Erdal, 2004, 301302). Furthermore, in some instances such as küdä-gü 'bride-groom' (Clauson, 1972, 703a),

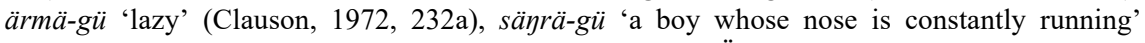
(Clauson, 1972, 841b), qori- $\gamma u$ 'the guard (BQ E 41)' (Ölmez, 2012, 316) etc. it reflects personal characteristics. This is why the author translates the lexeme kürägü as 'a runaway' here while Tekin $(1968,355)$ and Erdal $(2004,303)$ translated it as 'unruliness; obstinacy', as an abstract noun. At this point Erdal stated that it was the only instance of $-g U$ form with the abstract meaning in KT and BQ inscriptions. Nevertheless, it should be noted that the 'unruliness' and 'obstinacy' meanings of the lexeme kürägü are also imprecise and highly interpretative since the verb kürä- simply means 'to run away'. 
Turkic. (4) Furthermore, since yayilltï- $\gamma$ and kigürtü-g predicates of the sequential

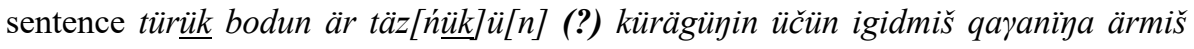

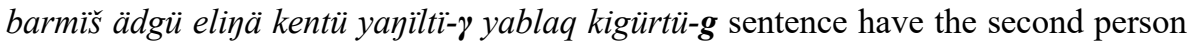
suffixes, the causal täz[ńük] ü[n] (?) kürägüyin üčün construction of the sentence should also carry the second person possessive suffix. ${ }^{15}$ Therefore, at first sight it

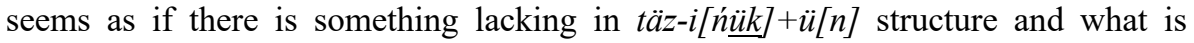
lacking here might be the second person possessive suffix. Thus, one possible solution could be to complete this structure with the second person possessive as täzi [ń $\underline{\ddot{u} k}]+\ddot{u}[y]+i[n]$ so that it can reflect the same grammatical structure with kürägü $+\eta+i n$.

As for the reason of the lack of the second person possessive in the original $<\mathrm{tz}[\mathrm{n}][\ddot{\mathrm{w} k}] \ddot{\mathrm{W}}[\mathrm{n}]>$ sign group, it might have occurred due to a scribal error. There were not many scribal errors in the Orkhon inscriptions, however, one may find some. According to Hovdhaugen $(1974,59)$ some scribal errors in the Orkhon inscriptions are as follows:

\begin{tabular}{|l|l|l|l|}
\hline erroneous forms & lines & correct forms & lines \\
\hline$<$ TBG $>$ & KT E 6 & $<$ TBGč $>$ & BQ E 6 \\
\hline$<$ bIlA $>$ & KT E 3 & $<$ bIlgA $>$ & BQ E 4 \\
\hline$<$ YWyšWRTIN $>$ & BQ E 7 & $<$ YWyšWRTwKKIN $>$ & KT E 6 \\
\hline$<$ WLRmD $>$ & KT E 27 & $<$ WLRmDm $>$ & BQ E 22 \\
\hline
\end{tabular}

Table 2: Some scribal errors in BQ and KT

As is known, a large part of the BQ and the KT were identical except for a few divergences. The mentioned passage in BQ E 19 was identical to the one in KT E 22-23. Nevertheless, since that part of the KT was not preserved even when the inscription was discovered, and we do not have the opportunity to compare, it will never be possible to know if there was a scribal error in BQ E 19 or not.

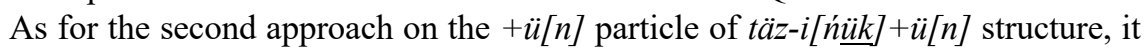
is theoretically possible to take it as the instrumental case suffix since the vowel of the instrumental case is subject to the vowel harmony. A possible transcription and translation with instrumental case might be as follows: tür $\underline{\ddot{k} k}$ bodun är

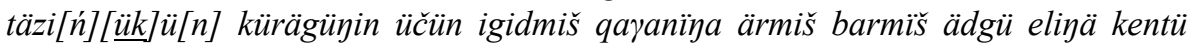
yayilltïy yablaq kigürtüg, which means "Oh Turkish people and men! Because of your act of running away with deserter(s), you yourself misbehaved against your Qayan who nourished you and, against your free and independent good realm, you

15 This harmony, of course, is valid if the subject of the basic sentence and the subordinative sentence with üčün are the same as in our instance. For further examples of this harmony, see KT S 8-9/BQ N 6; KT E 6/BQ E 6-7 etc. 
brought evil!"” as a whole. In this case, the proposed lexeme täzi[ń][ $\ddot{u k}]$ can still be interpreted as 'a deserter' as stated above while the suffix $-g U$ in kürä-gü- $\eta+i n$ structure can simply be taken as an action noun. If it would be so, there would be no need to assume a scribal mistake for a missing unwritten possessive suffix.

The solution above may seem more practical at first sight. However, the identical part of BQ E 19 which can be seen in KT E 22-23 prevents such an interpretation due to the fact that there was another $\ddot{u} c \ddot{u} n^{16}$ between the missing passage at the end of KT E 22 and the visible phrase kürägüyin üčün at the beginning of KT E 23. The fact that there was another $\ddot{u} c \ddot{u} n$ at the beginning of KT E 23 was stated by Clauson $(1972,111)$ before, and it can be proved by photograph no: 46 given by Aly1lmaz $(2005,42)^{17}$ :
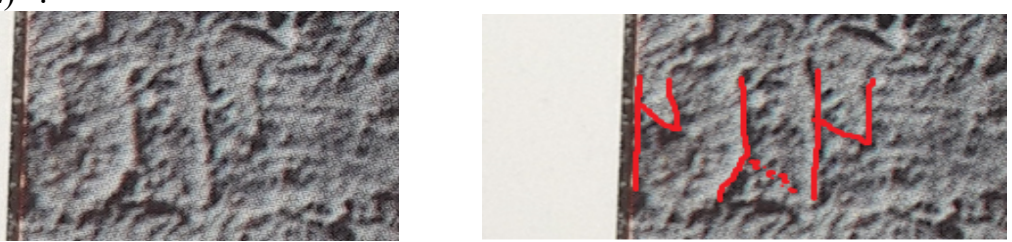

Figure 10: The sign group at the beginning of KT E 23

Therefore, it should be noted that the parallel passage in KT E was inscribed as

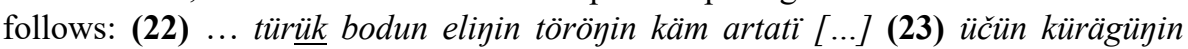
üčün... It is exactly this fact which makes an interpretation with instrumental case less acceptable. Because, if the missing passage in KT E 22-23 was taken as [tür $\underline{u} k$

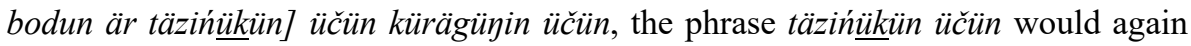
be ungrammatical because of the reasons already explained above.

As a result, in my humble opinion, it would be better to transcribe and translate the parallel passages in two inscriptions as follows:

BQ E ... (19) türükk bodun elinin töröyin käm artatï udači ärti türük bodun är

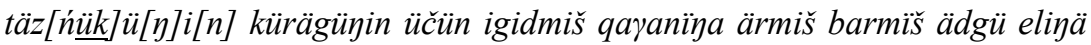
kentü yayïltïy yablaq kigürtüg

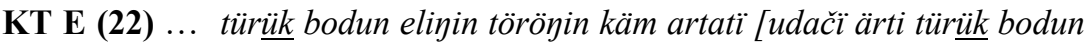

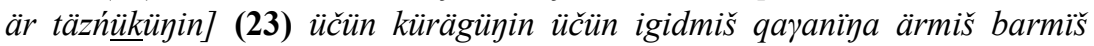

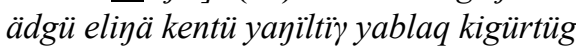

“... (oh) Turkic people, who would be able to disrupt your realm and your customary law? (Oh) Turkic people and men! (BK) Because you are

16 Many scholars reconstructed it by comparing with the parallel passage in the BQ as follows: KT E (22) ... türük bodun elinin töröyin käm artatï [udači ärti türükk bodun *ärtin] (23) *ökün kürägü̈in ǚ̈̈̈n... However, the missing passage in the KT E 22 could not end with the word *ärtin, because of the reasons already explained above.

17 The sign group can partially be seen in the photo as above. The one on the right is coloured by the author. 
deserter(s) (and) runaway(s) / (KT) Because you are deserter(s) (and) because you are runaway(s), you yourself misbehaved against your Qayan who nourished (you) and against your free and independent good realm, you brought evil!"”.

\section{Conclusion}

In this study, the problematic sequence in BQ E 19 was analysed from the vantage point of orthography and a solution was proposed for the problematic part. Here, the data in Finnish Atlas, Radloff's unretouched copy and an actual photograph taken by Ölmez was treated in detail and it was shown that the sequence in question contained no separation mark and $*<\ddot{\mathrm{W}}>$ before $[\ddot{\mathrm{W}} \mathrm{k}]$ in the middle. More crucially, the existence of a defective but still identifiable $<[n$ n $]>$ which had been inscribed before that $[\underline{\ddot{\mathrm{w}}}]$ and was not noticed by anyone until today was proved by means of a photograph of the inscription. Then the sequence was taken as $<\operatorname{rtz}[\mathrm{n}][\ddot{\mathbf{w} k}] \ddot{\mathrm{W}}[\mathrm{n}]>$ and re-evaluated as two independent units as $<\mathrm{r}>$ and $<\mathrm{tz}[\mathrm{n}][\ddot{\mathrm{w}}] \mathrm{W}[\mathrm{n}]>$. Accordingly, the former was read as är 'men' and the latter was read as täzi[n̈ük] ü[n].

The proposed noun stem täzi[ńük] 'deserter' was analysed as < täz- (verb 'to desert'), *-(I)n- (reflexive voice), *-yük (deverbal noun). Then the word

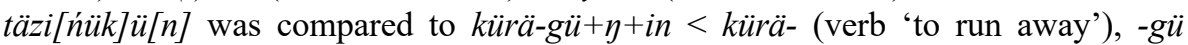
(deverbal noun), $+\eta$ (second person possessive), $+i n$ (accusative case coming after possessive) and täzi[ńük] $\ddot{u}[n]$ was proposed to be completed with the second person

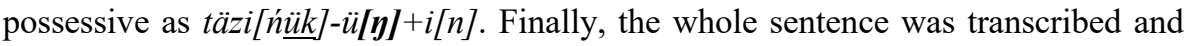

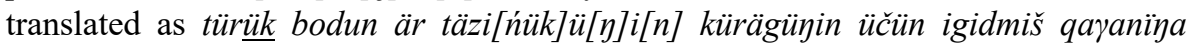

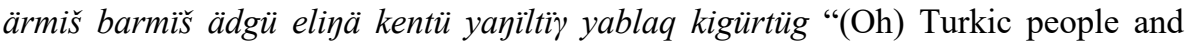
men! Because you are deserter(s) (and) runaway(s), you yourself misbehaved against your Qayan who nourished you and against your free and independent good realm, you brought evil!"'. This new reading proposal provides a new alternative to the former readings which were not in accordance with the real orthography of the mentioned sign group.

\section{References}

Alyılmaz, Cengiz (2005): Orhun Yazıtlarının Bugünkü Durumu. Ankara, Kurmay. Aydın, Erhan (2014): Orhon Yazıtları (Köl Tegin, Bilge Kağan, Tonyukuk, Ongi, Küli Çor). Konya, Kömen, 2nd ed.

Berta, Árpád (2004): Szavaimat jól halljátok... A türk és ujgur rovásírásos emlékek kritikai kiadása [Closely listen to my words ... A critical editon of records in Turkic and Uyghur runic scripts]. Szeged, Jatepress. 
Clauson, Sir Gerard (1972): An Etymological Dictionary of Pre-Thirteenth-Century Turkish. Oxford, Clarendon.

Gabain, Annamarie von (2000): Eski Türkçenin Grameri (trans. Mehmet Akalın). 3rd ed. Ankara, Türk Dil Kurumu Yayınları.

Heikel, Axel Olai et al. (1892): Inscriptions de l'Orkhon, recueilles par l'expédition finnoise de 1890 et publiées par la Société Finno-Ougrienne. Helsinfors.

Hovdhaugen, Even (1974): The Relationship Between the Two Orkhon Inscriptions. $A O H$ 36, pp. 54-82.

Orkun, Hüseyin Namı (1936): Eski Türk Yazıtları I. İstanbul, Türk Dil Kurumu Devlet Basımevi.

Ölmez, Mehmet (2012): Moğolistan'daki Eski Türk Yazıtları. Ankara, Bilgesu.

Radloff, Wilhelm (1893): Atlas der Alterthümer der Mongolei (Zweite Lieferung). St. Petersburg.

Radloff, Wilhelm (1895): Die alttürkischen Inschriften der Mongolei. St. Petersburg.

Tekin, Talat (1968): A Grammar of Orkhon Turkic. Bloomington, The Hague: Indiana University.

Tekin, Talat (1988): Orhon Yazıtları. Ankara, Türk Dil Kurumu Yayınları.

Thomsen, Wilhelm. (1893): Déchiffrement des inscriptions de l'Orkhon et de l'Iénisséi, notice préliminare. Bulletin de Academie Royale des Sciences et des Letters de Danemark, pp. 285-299.

Thomsen, Wilhelm. (1896): Inscriptions de l'Orkhon Déchiffrées. Helsingfors, Imprimerie de la Société de littérature finnoise.

Thomsen, Wilhelm. (1924): Alttürkische Inschriften aus der Mongolei in Übersetzung und mit Einleitung (trans. Hans Heinrich Schaeder). ZDMG Vol. 78, 1924/1925, pp. 121-175. 